Sibela Zvizdić,

Amela Dautbegović2

UDK : $616-057: 371.279 .2$

159.944.4:371.12.011.3-051

\title{
PREVENCIJA PROFESIONALNOG SAGORIJEVANJA NASTAVNIKA U VISOKOM OBRAZOVANJU
}

\section{- Sažetak -}

Uradu su prikazana osnovna obilježja stresa i profesionalnog sagorijevanja sa posebnim osvrtom na nastavnički stres i profesionalno sagorijevanje nastavnika iz visokog obrazovanja. Operacionalizirani su termini koji se najčešće koriste u izučavanju navedene problematike te su razmatrani faktori koji imaju značajnu ulogu u pojavi i prevenciji sagorijevanja na radu. Kada je u pitanju prevencija, autorice naglašavaju da je važnije identificirati i ako je moguće prevenirati i/ili eliminirati uzroke profesionalnog sagorijevanja nastavnika nego tretirati već razvijen sindrom sagorijevanja. S naglaskom na prevenciji, a koju je moguće realizirati na nivou organizacije i na individualnom nivou, navedene su smjernice $i$ obrazložene aktivnosti $u$ okviru prevencije profesionalnog sagorijevanja kod nastavnika zaposlenih $u$ institucijama visokog obrazovanja.

\section{Ključne riječi: profesionalno sagorijevanje, stres, prevencija, visoko obrazovanje.}

1 Dr. sc. Sibela Zvizdić, doktor psiholoških znanosti. U zvanju docenta zaposlena na Odsjeku za psihologiju Filozofskog fakulteta Univerziteta u Sarajevu na predmetima iz oblasti edukacijske psihologije i mentalnog zdravlja.

E-mail: sibela.zvizdic@gmail.com, sibela.zvizdic@ff.unsa.ba.

2 Mr. sc. Amela Dautbegović, magistrica psiholoških znanosti. Zaposlena na Odsjeku za psihologiju Filozofskog fakulteta Univerziteta u Sarajevu. U zvanju više asistentice angažovana na predmetima iz oblasti edukacijske psihologije i mentalnog zdravlja te na predmetu Zdravstvena psihologija. E-mail: amela.dautbegovic@ff.unsa.ba. 


\section{Stres i profesionalno sagorijevanje}

Termin stres je bio u upotrebi i prije njegovog razmatranja i proučavanja iz perspektive znanosti. U 14. stoljeću ovaj termin je bio u upotrebi kada su se nastojale označiti teškoće, tegobe i nesretne okolnosti, a njegova upotreba u znanstvenom kontekstu prvi put se javila u 17. stoljeću u okviru fizikalnih znanosti. Tek u 19. Stoljeću, o stresu se počinje raspravljati kao o uzroku bolesti (Lazarus i Folkman 2004) i to u okviru medicinskih nauka (HudekKnežević i Kardum 2006). Danas je jedna od najčešće citiranih definicija u znanstvenoj i stručnoj literaturi ona prema kojoj stres predstavlja stanje poremećene psihofizičke ravnoteže pojedinca nastalo bilo zbog fizičke bilo psihičke ili socijalne ugroženosti pojedinca ili njemu bliske osobe (Havelka 1998). Stres je veoma osobno iskustvo. Simptome stresa moguće je podijeliti na:

- bihevioralne (gubljenje stvari, veći broj nesreća, lakih udaraca i padova, manje pažnje za ličnu higijenu i dotjerivanje, pretjerano ili premalo konzumiranje hrane, korištenje psihoaktivnih supstanci, poteškoće spavanja);

- tjelesne (glavobolja, loša probava, koprivnjača, umor, iscrpljenost, gubitak energije, bol u leđima, prolazne vrtoglavice, srčane palpitacije);

- psihološke, u koje spadaju emocionalni i kognitivni simptomi. Emocionalni simptomi su: anksioznost/tenzija, iritabilnost/ gubitak kontrole/neobičan bijes, osjećaj skrhanosti, promjene raspoloženja, tuga, pretjerana zabrinutost. U kognitivne simptome spadaju: konfuzija, gubitak pamćenja, poteškoće u koncentriranju, nesposobnost donošenja odluka, zaboravljanje, reducirani raspon pažnje.

Termin profesionalno sagorijevanje (engl. burnout) uveden je u znanstvenu literaturu sedamdesetih godina prošloga stoljeća i to od strane američkog kliničkog psihologa njemačkog porijekla Herberta J. Freudenbergera i američkog psihologa Christine Maslach. Koncept profesionalnog sagorijevanja na poslu, dakle, prvi uvodi Freudenberger (1974.) te opisuje profesionalno sagorijevanje kao ...gubitak motivacije $i$ predanosti $u$ radu ljudi koji su izloženi učestalom i dugotrajnom stresu. (Martinko 2010: 100). Profesionalno sagorijevanje je fizički, mentalni i emocionalni odgovor na konstantne razine visokog stresa. Opisuje se kao niz tjelesnih i mentalnih simptoma iscrpljenosti, tj. kao odložen odgovor na hronične emocionalne 
i interpersonalne stresogene događaje na radnom mjestu (Maslach, Schaufeli i Leiter 2001). Termin burnout se još prevodi i kao 'izgaranje' ili 'pregorijevanje'.

Burnout traje tokom određenog perioda te predstavlja proces, a ne događaj, koji obično rezultira promjenom u stavovima, vrijednostima i emocijama prema poslu i klijentima (Pousette 2001). Vrhunac ovog procesa je gubitak "ispunjenosti" poslom.

Neophodno je razlikovati stres od profesionalnog sagorijevanja budući da burnout nije samo ekscesivan stres. Znakovi sagorijevanja su slični simptomima stresa, ali nisu identični. Znakovi burnouta su: manjak energije za rad, osjećaj tjelesne i emocionalne iscrpljenosti, hronični umor i slabost, preosjetljivost na podražaje, napetost mišića, bolna leđa, česte glavobolje i mučnine, problemi prehrane, gubitak težine, nesanica, gastrointestinalni poremećaji, učestalo obolijevanje, povećana upotreba alkohola, duhana, stimulirajućih sredstava i lijekova, osjećaj bespomoćnosti i beznađa, sklonost suzama, a ponekad i nekontroliranom plaču, nedostatak emocionalne energije nužne za svakodnevne životne aktivnosti, tzv. osjećaj da više nemamo šta da ponudimo. Prisutna je i razdražljivost te niska tolerancija na frustraciju, bijes, učestaliji sukobi i agresivni ispadi, smanjeno uživanje na poslu i u kontaktima s drugim ljudima, a što obično rezultira usamljenošću, obeshrabrenošću i razočarenjem. U znakove profesionalnog sagorijevanja spada gubitak zanimanja za suradnike i neosjetljivost za druge, gubitak osjećaja osobne vrijednosti, samokritičnost, sumnjičavost, rigidnost, neprilagodljivost, osjećaj inferiornosti, nekompetentnosti, gubitak seksualnog interesa i pojava seksualnih problema, neodlučnost, pesimizam, osjećaji hladnoće i mrzovolje koji nikada prije nisu doživljeni, cinizam, negativno procjenjivanje drugih ljudi (npr. studenata, kolega, prijatelja), negativizam vezan za sebe i za ciljeve posla ili organizaciju u kojoj radi (negativni stavovi prema sebi, poslu i samom životu) te izražene komunikacijske poteškoće.

Postoje tri dimenzije profesionalnog sagorijevanja (Maslach, Schaufeli i Leiter 2001):

1) emocionalna iscrpljenost;

2) depersonalizacija;

3) percepcija smanjene profesionalne efikasnosti (percepcija smanjenog osobnog postignuća).

Emocionalna iscrpljenost odnosi se na osjećanja emocionalne preopterećenosti i iscrpljenost zbog posla (Rakovec-Felser 2011). Depersonalizacija se može izraziti kroz negativne stavove prema klijentima 
i radnom okruženju (Kovacs 2010) te izražen cinizam. Prema rezultatima istraživanja, povećani zahtjevi na radnom mjestu (npr. previše poslova u prekratkom vremenu) su snažno i konzistentno povezani s profesionalnim sagorijevanjem, posebno s dimenzijom emocionalne iscrpljenosti (Maslach, Schaufeli i Leiter 2001).

Izazovi na poslu nisu isto što i profesionalno sagorijevanje. Naime, za izazov na poslu je karakterističan porast energije na psihološkom i fiziološkom planu, zatim motivacija za učenje novih vještina i za savladavanje zadataka, osjećaj relaksiranosti i zadovoljstva te zdrav i produktivan rad. Sagorijevanje se javlja kada izazov postane zahtjev posla koji se ne može savladati, kada osjećaj relaksiranosti biva zamijenjen iscrpljenošću i kada se zadovoljstvo pretvori u osjećaj stresa.

\section{Ko je podložan profesionalnom sagorijevanju?}

Sagorijevanje ovisi o:

- faktorima vezanim za posao/rad (šta osoba radi, gdje radi i sl.);

- ličnim faktorima (demografske karakteristike, osobine ličnosti, odnos prema radnom mjestu, stil suočavanja i sl.).

Stres na poslu izazivaju: zahtjevi posla, fizičko okruženje, radni odnosi (interpersonalni odnosi), stil rukovođenja, karakteristike organizacije, ekonomska stabilnost i sigurnost posla. Poslovi koji imaju veliki potencijal za burnout su oni koji zahtijevaju veliku odgovornost za druge ljude (npr. nastavnici, psiholozi, pedagozi, liječnici, sudije...), koji predstavljaju ekstremno repetitivan posao, posao pod vremenskim ograničenjem. Smatra se da je profesionalno sagorijevanje karakteristično za osobe koje rade $\mathrm{s}$ drugim ljudima te da je povezano sa situacijama u kojima se osoba osjeća preopterećenom poslom, podcijenjenom, zbunjenom oko očekivanja i prioriteta, zabrinutom zbog sigurnosti posla te pretjerano odgovornom zbog obaveza.

Osobe kod kojih postoji veći rizik za profesionalno sagorijevanje su obično moralne, dinamične, talentovane osobe koje su perfekcionisti u poslu te koje su u potpunosti posvećene radu. To su osobe kojima je posao jedino područje potvrđivanja. Pretjerano su vezane za posao te imaju visoka nerealna očekivanja od posla i od sebe. Imaju poteškoća u uspostavljanju osobnih limita, jer vjeruju samo sebi, te nisu u stanju delegirati poslove drugima. Veoma su uporne, često tvrdoglave i rigidne u postizanju cilja te imaju izraženu potrebu za uspjehom. Nadalje, osobe podložne profesionalnom sagorijevanju imaju 
potrebu za stalnom i potpunom kontrolom situacije na poslu te pokazuju potrebu da se osjećaju neophodnima. Imaju izraženu potrebu za odobravanjem od strane osoba iz okruženja te često osjećaju pretjeranu odgovornost za druge ljude (ekscesivna empatija koja iscrpljuje). Profesionalno sagorijevanje je prisutnije kod osoba s eksternalnim lokusom kontrole (osobe koje su uvjerene da sudbina, predodređenost, sreća i slučajnost određuju šta će im se dogoditi, odnosno kakvi će biti ishodi njihovih ponašanja) u odnosu na osobe sa internalnim lokusom kontrole (osobe kod kojih je izraženo uvjerenje da mogu uticati na životne događaje i njihove ishode) (Rakovec-Felser 2011) te kod osoba s nižim samopoštovanjem i izbjegavanjem kao stilom suočavanja (Semmer 1996; prema Rakovec-Felser 2011).

Najčešće posljedice profesionalnog sagorijevanja su:

- $\quad$ snižen moral i produktivnost;

- povećana odsutnost sa posla;

- napuštanje posla ili dobijanje otkaza (Rakovec-Felser 2011).

Zdravstvene posljedice profesionalnog sagorijevanja su: zloupotreba sredstava ovisnosti, anksioznost, depresija, snižena razina samopoštovanja (Maslach, Schaufeli i Leiter 2001).

\section{Nastavnički stres i profesionalno sagorijevanje nastavnika u visokom obrazovanju}

Nastavničko zvanje je vrlo stresna i zahtjevna profesija. Nastavnik u visokom obrazovanju ima više uloga:

- znanstvenik koji se bavi znanstveno-istraživačkim radom;

- nastavnik koji satima radi na poslovima vezanim za poučavanje (pripreme za nastavu);

- nastavnik koji poučava i voditelj koji motivira studente za učenje;

- nastavnik koji provjerava i vrednuje znanja studenata;

- nastavnik koji mnogo vremena potroši na administrativne poslove vezane za istraživanja, nastavu i studente;

- učenik kroz cjeloživotno obrazovanje.

Izvori stresa u našem kontekstu kod nastavnika iz visokog obrazovanja mogu biti siromaštvo radnih uvjeta (nedostatak ljudskih i materijalnih resursa), nizak socijalni status nastavničke profesije uz nedostatak adekvatnog vrednovanja nastavnika (nastavnici nisu dovoljno plaćeni za svoj rad i zalaganje), loši međuljudski odnosi (izostanak podrške kolega na poslu i/ili nedostatak timskog rada s kolegama), posljedice provedbe bolonjske reforme, 
nedovoljno ili gotovo nikakvo učestvovanje u donošenju odluka koje se tiču visokog obrazovanja, slabe prilike za napredovanje u karijeri, izražen vremenski pritisak uz povećan broj nastavnih sati, predugo neposredno angažiranje u radu sa studentima, slabo pripremljeni studenti, površna komunikacija na relaciji student - nastavnik, povećana birokratizacija, otežavajuća uloga žene-nastavnika u smislu opterećenja različitim ulogama (zahtjevi karijere, briga o djeci, obiteljske i općenito kućne obaveze) uz konflikt uloga koji može rezultirati kompeticijom sa suprugom (kompeticija oko dnevnog rasporeda obaveza, finansije i sl.).

Autorice Slišković, Maslić Seršić i Burić (2012.) iz Hrvatske navode da je u posljednjih dvadesetak godina u visokom obrazovanju došlo do značajnijih promjena. Naime, prisutan je porast broja studenata koji nije praćen dovoljnim porastom broja nastavnika, što je dovelo do porasta broja radnih sati nastavnika (Cownie 2004; Gillespie i sur. 2001; Kinman 1998; Kinman i Jones 2008b; Parry i sur. 2008; Shaw i Cassell 2007; Tytherleigh 2003; Winefield i Jarett 2001; prema Slišković, Maslić Seršić i Burić 2012). Karakteristične su i promjene u načinu studiranja, gdje je naglasak na mentorskom radu i nastavi u manjim grupama (Parry i sur. 2008; prema Slišković, Maslić Seršić i Burić 2012), a to znači više nastavnih i administrativnih obaveza za nastavnike u visokom obrazovanju. Nadalje, Slišković i suradnice (2012: 84) ističu da je uočljiv ...veći broj studenata koji plaćaju studij, internacionalnih studenata te manje kvalitetnih studenata... uz povećana očekivanja studenata o dostupnosti nastavnika.

\section{Rezultati istraživanja ukazuju da u izvore stresa na poslu za visokoškolske nastavnike spadaju:}

- manjak ljudskih i materijalnih resursa (Gillespie i sur. 2001; prema Slišković, Maslić Seršić i Burić 2012);

- nesigurnost posla i otežana mogućnost napredovanja (Gillespie i sur. 2001; Kinman 1998; prema Slišković, Maslić Seršić i Burić 2012);

- loši međuljudski odnosi, osobito nedostatak podrške kolega i/ili nadređenih (npr. Narayanan, Menon i Spector 1999; prema Slišković, Maslić Seršić i Burić 2012);

- osjećaj podcijenjenosti i nedovoljne plaćenosti posla koji obavljaju (Barkhuizen i Rothmann 2008; Gillespie i sur. 2001; prema Slišković, Maslić Seršić i Burić 2012);

- radni zadaci prelaze okvire zakonom propisanih zahtjeva posla (Kinman 1998; Thorsen 1996; Tytherleigh 2003; prema Slišković, Maslić Seršić i Burić 2012); 
- doživljaj vremenskoga pritiska zbog prevelikoga broja nastavnih, istraživačkih i administrativnih obaveza (Barkhuizen i Rothmann 2008; Gillespie i sur. 2001; Kinman 1998; Thorsen 1996; prema Slišković, Maslić Seršić i Burić 2012);

- izraženi zahtjevi za istraživanjima (Blix, Cruise, Mitchell i Blix 1994; prema Salami 2011), s tim da istraživači konzistentno izvještavaju o vremenskom pritisku (Barnes, Agago i Combs 1998; prema Salami 2011);

- mnogobrojni stresori u istraživačkoj domeni, s tim da se od nastavnika/ znanstvenika zahtijevaju vještine prikupljanja materijalnih sredstava za istraživačke projekte (Cownie 2004; prema Slišković, Maslić Seršić i Burić 2012);

- $\quad$ pritisak za objavljivanjem, koji stalno raste (Blix, Cruise, Mitchell i Blix 1994; prema Salami 2011; Cownie 2004; Kinman 1998; prema Slišković, Maslić Seršić i Burić 2012) i koji demoralizira nastavnike (Gillespie i sur. 2001; prema Slišković, Maslić Seršić i Burić 2012);

- podučavanje sve većeg broja studenata koji su zahtjevniji (Gillespie i sur. 2001; prema Slišković, Maslić Seršić i Burić 2012);

- prilagođavanje novim programima studiranja (Parry i sur. 2008; prema Slišković, Maslić Seršić i Burić 2012);

- $\quad$ prisutnost kontrole kvalitete podučavanja (Cownie 2004; Winefield i sur. 2003; prema Slišković, Maslić Seršić i Burić 2012);

- visoka očekivanja od strane samih nastavnika (Smith, Anderson i Lovrich 1995; prema Salami 2011);

- suočavanje s vlastitim negativnim emocionalnim reakcijama (Carson, Templin i Weiss 2006; Montgomery i Rupp 2005; Sutton 2004; prema Jennings i Greenberg 2009) pošto su nastavnici konstantno izloženi emocionalno provokativnim situacijama. Naime, kada situacija isprovocira snažnu emocionalnu reakciju, nastavnici imaju ograničene opcije za samoregulaciju (npr. kada se osjeti uznemirenim, nastavnik je obavezan ostati u razredu sa studentima, što znači da nije u mogućnosti napustiti nastavu dok se ne smiri). Negativne emocionalne reakcije mogu djelovati na kognitivno funkcioniranje nastavnika i na njegovu motivaciju, a nepoželjni oblici ponašanja studenata često izazivaju ometajuće negativne emocije koje se mogu negativno odraziti na podučavanje (Emmer 1994; Emmer i Stough 2001; International Labour Office 1993; prema Jennings i Greenberg 2009); 
- zbog preopterećenosti istraživačko-nastavnim i administrativnim obavezama postaje nejasna granica koja dijeli radni i privatni život nastavnika (Barkhuizen i Rothmann 2008; Cownie 2004; Kinman i Jones 2008a, Kinman i Jones 2008b; Tytherleigh i sur. 2005; prema Slišković, Maslić Seršić i Burić 2012).

Opadanje broja kandidata koji se žele baviti nastavničkim zanimanjem, češće obolijevanje nastavnika od psihosomatskih oboljenja od ljudi koji se bave drugim zanimanjima, povećan broj nastavnika koji odlaze u prijevremenu penziju predstavljaju samo neke od posljedica izloženosti nastavnika iz visokog obrazovanja mnogobrojnim stresorima na poslu.

\section{Na temelju rezultata dosadašnjih istraživanja, utvrđene su posljedice djelovanja mnogobrojnih stresora na poslu kod visokoškolskih nastavnika:}

- preokupiranost poslom može ometati spavanje ili opuštanje u slobodnim trenucima (Slišković, Maslić Seršić i Burić 2012);

- niže razine psihičke dobrobiti (Barkhuizen i Rothmann 2008; Winefield i sur. 2003; prema Slišković, Maslić Seršić i Burić 2012);

- povišene razine sagorijevanja na poslu (Lackritz 2004; prema Slišković, Maslić Seršić i Burić 2012; Salami 2011);

- često doživljavanje frustracija i negativnih emocija (npr. ljutnje, krivnje i tuge) kod nastavnika može reducirati intrinzičnu motivaciju i osjećaj samoefikasnosti te tako dovesti do profesionalnog sagorijevanja (Kavanaugh i Bower 1985; prema Jennings i Greenberg 2009);

- psihosomatska oboljenja (Blix i sur. 1994; Gillespie i sur. 2001; Kinman 1998; prema Slišković, Maslić Seršić i Burić 2012);

- opadanje zadovoljstva poslom (Kinman 1998; prema Slišković, Maslić Seršić i Burić 2012);

- smanjenje radnog učinka (Barkhuizen i Rothmann 2008; Jacobs, Tytherleigh, Webb i Cooper 2007; Parry i sur. 2008; prema Slišković, Maslić Seršić i Burić 2012);

- nezadovoljstvo poslom (Kinman i Jones 2008; prema Slišković, Maslić Seršić i Burić 2012) i visoka razina namjere napuštanja posla (Barkhuizen i Rothmann 2008; Gillespie i sur. 2001; Kinman i Jones 2008; prema Slišković, Maslić Seršić i Burić 2012). 
Općenito, profesionalno sagorijevanje može imati negativan utjecaj na emocionalno i fizičko zdravlje te sreću nastavnika. Također, može imati negativan utjecaj i na studente budući da nastavnik koji sagorijeva ima slabiji kvalitet podučavanja, manje je empatičan i posvećen poslu, manje je u interakciji sa studentima, te im može pružati manje informacija i manje potkrepljenja (Salami 2011). S obzirom na velik broj stresora sa kojima se nastavnici iz visokog obrazovanja svakodnevno susreću sasvim je očekivano da na koncu imamo nastavnika koji je emocionalno „potrošen“ i profesionalno neefikasan te koji ima poteškoća $u$ interakciji ne samo sa studentima već i s radnim kolegama i članovima obitelji.

S druge strane, Fredrickson (2001; prema Jennings i Greenberg 2009) te Gu i Day (in press; prema Jennings i Greenberg 2009) navode da nastavnici koji redovito doživljavaju više pozitivnih emocija u radu mogu biti rezilijentniji. Faktori koji su povezani sa rezilijencijom nastavnika su:

- visoko samopoštovanje i povjerenje u vlastite snage i sposobnosti;

- kapacitet za osmišljavanje realističnih planova te koraka za njihovu realizaciju;

- razvijene komunikacijske vještine i vještine rješavanja problema;

- postojanje kapaciteta za savladavanje snažnih emocija i impulsa.

Zapravo, rezilijentniji nastavnici posjeduju razvijene vještine traženja pomoći, savjeta ili resursa kada su im isti neophodni te imaju efikasne pristupe u rješavanju problema. Za njih je karakteristično i traganje za najboljim načinima balansiranja radnog i privatnog života pa su samim tim i manje pod rizikom za profesionalno sagorijevanje.

\section{Prevencija profesionalnog sagorijevanja nastavnika iz visokog obrazovanja}

Kada je u pitanju prevencija profesionalnog sagorijevanja, mnogo je važnije identificirati i ako je moguće prevenirati i/ili eliminirati uzroke nastavničkog burnouta nego tretirati već razvijen sindrom sagorijevanja. Prevenciju profesionalnog sagorijevanja moguće je realizirati kroz tri nivoa preventivnih intervencija:

1) primarna prevencija, čiji je cilj spriječiti pojavu mentalnozdravstvenih problema, potaknuti osobni rast i razvoj te reducirati stopu incidencije, dakle broj novih slučajeva profesionalnog sagorijevanja;

2) sekundarna prevencija, čiji je cilj rana identifikacija i tretman prvih simptoma prije nego se potpuno razvije sindrom sagorijevanja 
tj. reduciranje negativnog djelovanja stresora te preveniranje progresivnog razvoja mentalnozdravstvenih problema;

3) tercijarna prevencija, u okviru koje osoba koja je nedavno patila od poremećaja prima određeni vid intervencije kako bi joj se olakšali oporavak i rehabilitacija te preveniralo ponovno javljanje profesionalnog sagorijevanja (Conyne 1991).

Ove preventivne intervencije moguće je realizirati na nivou organizacije (promjene u okviru akademskog okruženja) i na individualnom nivou (cilj je osnažiti nastavnikove resurse za suočavanje sa stresom).

\section{Primarna prevencija}

Napori stručnjaka u okviru primarne prevencije idu u smjeru modifikacije nastavničkog posla s ciljem da nastavnici imaju više kontrole nad njihovim poslovnim okruženjem te više resursa za suočavanje sa svakodnevnim zahtjevima i izazovima nastavničkog posla (Wood i McCarthy 2002). Ovaj nivo prevencije bavi se uklanjanjem faktora rizika i uzroka koji mogu dovesti do profesionalnog sagorijevanja.

Prevencija profesionalnog sagorijevanja podrazumijeva ovladavanje stresom uz organizacijske promjene, što rezultira zdravim radnim mjestom za nastavnike. Ovladavanje stresom znači edukaciju nastavnika o prirodi stresa i njegovim izvorima, o utjecaju stresa na čovjekovo fizičko i mentalno zdravlje te o vještinama za reduciranje stresa (npr. upravljanje vremenom ili vježbe relaksacije). Primarna prevencija profesionalnog sagorijevanja nastavnika na individualnom nivou odnosi se i na jačanje samoefikasnosti i sposobnosti da se zadrži pozitivna perspektiva vezano za dnevne događaje, što značajno ublažava anksioznost nastavnika (Greenberg 1999; prema Wood i McCarthy 2002). Organizacijske promjene podrazumijevaju poboljšanje radnih uvjeta, identificiranja stresogenih aspekata rada i osmišljavanje strategija za reduciranje i/ili eliminiranje identificiranih stresora, što zapravo predstavlja načine za reduciranje stresa na poslu. Poboljšanje radnih uvjeta podrazumijeva poboljšanje timske podrške, prepoznavanje potreba nastavnika (stimulacija), priznavanje uspjeha nastavnika, obezbjeđivanje permanentne edukacije stručno usavršavanje te obezbjeđivanje uvjeta za razvoj karijere. 
Strategije za preveniranje profesionalnog sagorijevanja nastavnika

Budući da se nastavnici često osjećaju izoliranim uprkos prisustva većeg broja kolega koji rade u istoj zgradi, neophodno je da nastavnici traže pomoć i inspiraciju upravo od svojih kolega. Naime, akademska institucija bi trebala omogućiti nastavnicima da budu u interakciji tj. da surađuju, razmjenjuju ideje, opserviraju jedni druge te da učestvuju u grupnom rješavanju problema. Nadalje, poželjno je povezati se sa iskusnim, kvalitetnim nastavnicima putem interneta te posjećivati blogove za edukatore s ciljem prikupljanja informacija o uspjesima i izazovima s kojima se suočavaju drugi prosvjetni radnici (Provini 2013). Za reduciranje razine stresa korisno je i podijeliti posao s kolegama. Ukoliko okolnosti dozvoljavaju, dobro je s drugim nastavnikom zajedno planirati predavanja, seminare i druge aktivnosti sa studentima. S vremena na vrijeme neophodno je da nastavnici svoje vrijeme za pauzu provedu s drugim kolegama, kako bi imali priliku razgovarati, podijeliti poslovna iskustva te općenito bolje upoznati druge kolege-nastavnike.

Neophodno je fokusirati se na ono što nastavnik dobro obavlja (Provini 2013). Naime, sa tako mnogo izazova tokom radnog dana veoma je lako biti usmjeren samo na negativna dešavanja i negativne stvari te je stoga neophodno načiniti listu manjih uspjeha, poboljšanja u radu, dakle, stvari u kojima nastavnik uživa te dostignuća na koja je nastavnik ponosan. Nakon teškog dana ili kada god postoji potreba za opuštanjem autorica Provini (2013) preporučuje ponovno čitanje liste sa pozitivnim stvarima, jer će to nastavnicima omogućiti da ostanu svjesni svih pozitivnih događaja te će im pomoći da cijene izazove i nagrade koje im donosi nastavnički posao.

Postavljanje ciljeva i izazova je veoma važno. Ciljevi usmjeravaju našu pažnju na zadatak, mobiliziraju napor, povećavaju upornost i promoviraju razvoj novih strategija kada stare strategije zakažu. Utvrđeno je da specifični, umjereno teški ciljevi, za koje postoji vjerovatnoća da će biti ostvareni u bliskoj budućnosti, povećavaju motivaciju i upornost (Pintrich i Schunk 1996; prema Slavin 2009). Specifični ciljevi nude jasne standarde za prosuđivanje realizacije cilja, dok umjereno teški ciljevi nude razuman izazov za pojedinca. Važni su jasno definirani ciljevi, koji su konkretni, specifični, realni i smisleni (Erez i Zidon 1984; prema Slavin 2009) te ostvarivi u životnom kontekstu nastavnika. Nadalje, ciljevi koji se odnose na osobni profesionalni razvoj pomažu nastavnicima da se podsjete zašto su se počeli baviti nastavničkom profesijom. Cjeloživotno obrazovanje, učenje, je odličan način da se zadrži pozitivan odnos prema radu. Nastavnici mogu izabrati jednu ili više oblasti u kojima se žele usavršavati. Kada se osjete preplavljeni fakultetskim zahtjevima, 
samoinicijativno mogu koristiti materijale iz raznih izvora (biblioteka, medija i sl.) kojima bi mogli obogatiti nastavni silabus te omogućiti sebi distancu od jednolične svakodnevice. Trebaju čitati i primjenjivati sve ono što se odnosi na tehnike jačanja samopoštovanja.

U prevenciji profesionalnog sagorijevanja neophodno je naučiti kvalitetno upravljati vremenom. Budući da posao nastavnika zapravo nikada ne prestaje, neophodno je da nastavnici nauče ne nositi posao kući, što predstavlja veoma korisnu strategiju za reduciranje stresa. Samim tim naučit će uživati u drugim stvarima nakon posla, osobito sa članovima svoje obitelji. Visokoškolski nastavnici ne bi trebali dozvoliti drugima da kontroliraju njihov dnevni raspored te je poželjno unaprijed obavijestiti kolege i bliske osobe o vlastitim vremenskim ograničenjima. Potrebno je odrediti prioritete u poslu te isplanirati pauze između obaveza. Prioritetne stvari treba obavljati jednu po jednu, nikada sve zajedno. Nadalje, rutinske zadatke treba raditi jednom dnevno, po mogućnosti u isto vrijeme, a monotone poslove bi trebalo slijediti zanimljivim. Nastavnici trebaju naučiti delegirati poslove i odgovornosti. Dakle, nije poželjno pretrpavati se dnevnim obavezama te je važno naučiti potkrepljivati se za efikasno riješene radne izazove.

Radi što boljeg upravljanja vremenom, nastavnicima se preporučuje da ranije dolaze na posao kako bi imali mogućnost da na miru pregledaju pripremu za predavanje, da pripreme materijale za studente ili, pak, da obave hitne administrativne poslove vezane za fakultet. Raniji dolazak na posao nastavnicima će omogućiti potpunu posvećenost studentima za vrijeme nastave, obavljanje posla bez stresa i uživanje s prijateljima ili članovima obitelji nakon posla. Nadalje, poželjno je da nastavnici već u petak, tokom radnih sati, isplaniraju i pripreme se za sve aktivnosti koje ih očekuju naredne sedmice. Na taj način će vrlo efikasno izbjeći rad kod kuće tokom vikenda te paniku i stres koji se obično javljaju u nedjelju poslijepodne. Dakle, nije poželjno opteretiti se poslovnim brigama tokom vikenda, kada se svakako očekuju mnogobrojni kućni poslovi te kada je neophodno odmoriti se od poslovnih aktivnosti i obaveza. Vikende treba iskoristiti za putovanja ili druženja s bliskim ljudima. S vremena na vrijeme nastavnici bi trebali iskoristiti dio svoga odmora (ljeti i zimi) samo za relaksaciju. Zato je neophodno isplanirati vrijeme za neometano opuštanje i razmišljanje te pokušati izbjegavati stalnu brigu. Bilo bi poželjno obezbijediti nastavnicima prostor bez buke, gdje bi se mogli opustiti, uživati u tišini tokom radnog dana ili gdje bi imali mogućnost uživati u aktivnostima poput slušanja muzike ili crtanja i sl. 
Razvijanje otpornosti na stres moguće je pravilnim balansom odnosno ravnotežom života u smislu ispravne podjele vremena na poslovni, obiteljski i društveni život (fizičke, intelektualne i duhovne aktivnosti, kultura i sl.). Na individualnom nivou (Kyriacou 2001; prema Amimo 2012) nastavnici trebaju organizirati osobne živote koristeći zdravu ishranu, relaksaciju i savladavanje osobnih životnih stresora. Tjelesnu i psihološku otpornost mogu steći zdravim životnim navikama (tjelovježbom ili bavljenjem sportom, kvalitetnom ishranom i dovoljnom količinom sna), kvalitetnim upravljanjem vremenom i postavljanjem poslovnih prioriteta, bavljenjem hobijima (rekreacija, kultura i sl.), održavanjem stabilnih odnosa s bliskim osobama, treningom asertivnosti, učenjem tehnika relaksacije te izgrađivanjem tolerancije na frustraciju. Iako postoji potreba za reduciranjem zahtjeva koji se postavljaju pred nastavnike, kontinuiranom edukacijom i razvojem univerziteta, neophodno je raditi i na osnaživanju njihove samoefikasnosti i kompetencija te autoriteta u donošenju odluka. Na kraju, ne treba zaboraviti da se za religiju i spiritualnost ističe da imaju potencijalno preventivnu funkciju.

Primarna prevencija profesionalnog sagorijevanja nastavnika na organizacijskom nivou se odnosi na dozvoljavanje nastavnicima da imaju kontrolu nad njihovim dnevnim izazovima.

Kyriacou (2001; prema Amimo 2012; Wood i McCarthy 2002) predlaže slijedeće primarno preventivne korake na organizacijskom nivou, koji mogu reducirati stres kod nastavnika:

- Prilikom razvoja nastavnih planova i programa, zatim predmetnih silabusa, planiranja instrukcija te drugih stručnih stvari, neophodno je konsultirati se s nastavnicima, što ima direktan utjecaj na njihove razrede.

- Obezbijediti adekvatne resurse i uvjete kako bi se pružila podrška nastavniku u praksi.

- Obezbijediti jasan opis posla i jasna očekivanja s ciljem izbjegavanja konflikta i nejasnoća s radnom ulogom.

- Uspostaviti i očuvati otvorenu komunikaciju između nastavnika, studenata i fakultetskih administrativnih službi pružanja administrativne podrške i povratne informacije o izvedbi, a koje mogu ublažiti djelovanje stresora.

- Dozvoliti i ohrabrivati razvojne profesionalne aktivnosti, poput mentorstva i umrežavanja nastavnika, koje bi trebale značajno doprinijeti osjećaju ostvarenosti i potpunijeg profesionalnog identiteta nastavnika. 
- Edukacijama i treninzima za nastavnike moguće je unaprijediti kompetencije nastavnika, a samim time poboljšati kvalitetu univerzitetskog okruženja. Također, kroz cjeloživotno obrazovanje nastavnika te obezbjeđivanje mentorstva za nastavnike početnike moguće je značajno pomoći nastavnicima da razviju svoje kompetencije kada je u pitanju rukovođenje razredom, realizacija sadržaja silabusa i metode poučavanja. Trebalo bi im obezbijediti edukacije, radionice iz područja kojima se bave, dakle kontinuirano usavršavanje kako bi povratili entuzijazam i osjećaj samoefikasnosti.

- Neophodno je graditi profesionalnu zajednicu s ciljem obezbjeđivanja konstantne podrške, motivacije i kapaciteta koji omogućavaju nastavnicima da ponovno počnu cijeniti svoj poziv te da se identificiraju s kulturom poučavanja.

- Pomoći nastavnicima da razviju novi tip profesionalizma koji im omogućava inkorporiranje novih tehnologija u nastavu, organizacijsku kompetentnost, suradnju, fleksibilnost i mobilnost s ciljem uklapanja u novu ulogu koju univerzitet ima kao obrazovna institucija.

Općenito, mjere na radnom mjestu obuhvataju: kreiranje zdravog radnog okruženja, prepoznavanje učinka nastavnika na radu (nagrade, priznanja, novac i sl.), uz edukacije administrativnog osoblja i uprave fakulteta, koji imaju ključnu ulogu u preveniranju profesionalnog sagorijevanja njihovih radnika tj. nastavnika.

\section{Sekundarna prevencija}

Fokus sekundarne prevencije je na ranoj detekciji problema prije nego dođe do potpunog razvoja poteškoća. U okviru sekundarne prevencije iznimno je važna rana identifikacija (prepoznavanje prvih simptoma) te intervencije prije nego se potpuno razvije sindrom profesionalnog sagorijevanja. Dakle, cilj je reducirati negativno djelovanje stresora te prevenirati progresivni razvoj mentalnozdravstvenih problema kod nastavnika.

Amimo (2012) ističe da simptomi nastavničkog stresa, koji doprinose razvoju profesionalnog sagorijevanja, mogu imati različite forme ispoljavanja. Na temelju rezultata istraživanja (Brown i Ralph 1998; Hinton i Rotheiler 1998; Kyriacou 2001; Troman i Woods 2001; prema Wood i McCarthy 2002) utvrđeni su rani simptomi nastavničkog stresa i sagorijevanja: potreba da se ne ide na posao ili stvarno izostajanje s posla, poteškoće pri koncentriranju na zadatke, osjećaj prenatrpanosti poslovima uz osjećaj neadekvatnosti za 
obavljanje postavljenih zadataka, osjećaj gubitka kapaciteta i nesposobnost za profesionalno obavljanje nastavničkog posla, povlačenje od kolega ili pak upadanje u konfliktne odnose sa suradnicima, studentima te općenito iritabilnost vezana za fakultet, insomnija, poremećaji digestivnog trakta, glavobolje, srčane palpitacije i druge fiziološke reakcije. Savladavanje stresa, treninzi relaksacije, meditacije, uz poboljšanje radnih uvjeta mogu pomoći nastavnicima u ovoj fazi (Amimo 2012).

Ukoliko se kod nastavnika javljaju prvi simptomi sagorijevanja, neophodne su određene aktivnosti kako bi se poboljšalo tjelesno, mentalno i socijalno stanje nastavnika. Naime, neophodno je da nastavnik posjeti liječnika i obavi sistematski pregled. Važan je odmor nastavnika s ciljem potpunog tjelesnog obnavljanja uz zdravu ishranu i tjelovježbe (vježbe istezanja, duge šetnje) koje mogu osloboditi od tenzije. Usljed sagorijevanja na poslu nastavnici često osjećaju da pružaju veoma mnogo te da su konstantno u stanju stresa bez vremena za relaksaciju i uživanje u životu. Stoga se nastavnicima preporučuje: razvijanje strategija suočavanja sa stresom (tehnike mišične relaksacije, duboko disanje, tehnike samoohrabrivanja i optimistično redefiniranje situacije), prepoznavanje osobnih kapaciteta i slabosti s ciljem boljeg nošenja sa svakodnevnim stresorima, učenje upravljanjem vremenom kako bi nastavnik razvio balans i kontrolu nad poslovnim i privatnim životom. Potrebno je naučiti postavljati granice, tj. profesionalni ciljevi trebaju biti realni i ostvarivi (Dedić 2005), što omogućava smjer, jasnoću i fokus u životu nastavnika. Naime, osjećaj svrhe se javlja kroz učenje i traganje za novim ostvarenjima. Nastavnik treba sebe postaviti na prvo mjesto i pronaći vrijeme samo za sebe tokom kojeg će se baviti aktivnostima u kojima uživa.

Loši odnosi s drugim ljudima mogu doprinijeti razvoju profesionalnog sagorijevanja, dok pozitivni odnosi mogu pomoći u prevenciji ili reduciranju sagorijevanja. Zbog toga su neophodni koraci koji poboljšavaju odnose na poslu i u obitelji:

- njegovanje bliskih odnosa sa djecom, partnerom ili prijateljima ima velik značaj u reduciranju sagorijevanja budući da pozitivni odnosi obnavljaju energiju i eliminiraju osjećaj podcijenjenosti;

- razvijanje dobrih međuljudskih odnosa na poslu pošto podrška od kolega pospješuje rad i umanjuje faktore koji doprinose javljanju sindroma sagorijevanja na radu;

- uključivanje u socijalnu, religijsku ili suportivnu grupu važnu za nastavnika može zapravo obezbijediti mjesto za razgovore sa osobama koje slično razmišljaju o nošenju sa svakodnevnim stresorima; 
- učenje komunikacijskih vještina;

- nastavnik treba podijeliti svoje nezadovoljstvo poslom s nadređenim kako bi zajednički istražili opcije za reduciranje obaveza i ublažavanje stresa;

- ukoliko je neophodno, nastavnik treba razmotriti promjenu posla ili karijere.

\section{Tercijarna prevencija}

Tercijarna prevencija podrazumijeva suočavanje sa posljedicama profesionalnog sagorijevanja uključujući i rehabilitaciju i liječenje. Cilj je olakšati oporavak i rehabilitaciju te prevenirati ponovno javljanje profesionalnog sagorijevanja uz minimiziranje onesposobljenja. Ukoliko se utvrdi profesionalno sagorijevanje, neophodno je da nastavnik odluči da li može ili želi nastaviti sa svojim poslom. Naime, nekoliko faktora mogu utjecati na ovu odluku uključujući osobne faktore, godine nastavničkog staža, obiteljske obaveze, osobne finansije te tržište rada (Amimo 2012; Wood i McCarthy 2002). Mnogi nastavnici odlučuju napustiti posao. Drugi pak nemaju mogućnosti za promjenu karijere te su prinuđeni zadržati se na fakultetu.

U svom istraživanju, Troman i Woods (2001; prema Wood i McCarthy 2002) utvrdili su da postoje tri kategorije nastavničkih reakcija na stres i profesionalno sagorijevanje. Naime, pojedini nastavnici jednostavno prekinu svoju karijeru profesionalnih edukatora, dok drugi, pak, tragaju za olakšanjem i smanjenjem stresa tako što preuzimaju manje prestižne ili manje zahtjevne uloge ili, pak, počinju raditi pola radnog vremena. Treća grupa nastavnika se odlučuje za razvijanje interesovanja izvan svoje profesije, posvećujući više svog vremena obitelji i prijateljima ili se, ukoliko im to uslovi dozvoljavaju, prebacuju u drugo, pogodnije akademsko okruženje.

U svakom slučaju, razjašnjavanje institucionalnih vrijednosti i ciljeva te produbljivanje percepcije pripadnosti mogu poništiti simptome profesionalnog sagorijevanja (Skaalvik i Skaalvik 20011; prema Amimo 2012). Također, Amimo (2012) navodi da podrška od obitelji, prijatelja i radnih kolega, adekvatni fizički uvjeti, fleksibilna administrativna struktura, mogućnost mijenjanja zadataka i obaveza te jasna poslovna očekivanja mogu ublažiti i/ ili iskorijeniti simptome profesionanog sagorijevanja. 


\section{Zaključna razmatranja}

$\mathrm{Na}$ koncu, ključni elementi prevencije profesionalnog sagorijevanja su intervencije s fokusiranjem na radno okruženje, uz individualne intervencije. Zapravo, najefikasniji modeli intervencija predstavljaju kombinaciju intervencija na radnom mjestu i individualnih intervencija. Individualne intervencije uključuju razvijanje individualnih strategija kod nastavnika koje su usmjerene na jačanje unutarnjih resursa ili na promjene radnog ponašanja nastavnika (Rakovec-Felser 2001). Ipak, pristupi orijentirani na individuu (kognitivno-bihevioralne tehnike, relaksacija, meditacije, upravljanje vremenom, trening asertivnosti, racionalno-emotivna terapija, učenje interpersonalnih i socijalnih vještina, upravljanje profesionalnim zahtjevima i dr.) mogu pomoći osobi da prevlada iscrpljenost, ali se zapravo ne mogu nositi s druge dvije komponente burnouta (cinizam i neefikasnost). Istraživanja su pokazala da situacijski i organizacijski faktori imaju veću ulogu u profesionalnom sagorijevanju od onih individualnih, pa je stoga $i$ razumljivo da su individualne strategije relativno neefikasne na radnom mjestu, gdje nastavnik nema mnogo kontrole nad stresorima iz radnog okruženja (Rakovec-Felser 2001).

Savremeni stil života često podrazumijeva svakodnevno suočavanje sa stresom te sa sobom nosi i mnogo rizika za pojavu profesionalnog sagorijevanja. Zbog toga je od izuzetne važnosti da znanstvenici i stručnjaci ponude smjernice i preporuke koje će omogućiti uspješnije prepoznavanje i reduciranje kako stresa tako i profesionalnog sagorijevanja. Budući da institucije visokog obrazovanja predstavljaju kontekst u kojem ulaganje u pojedinca predstavlja ne samo individualni nego i društveni značaj, važno je osvijestiti problem profesionalnog sagorijevanja nastavnika i planirati aktivnosti koje će omogućiti prevenciju problema i poteškoća nastalih kao posljedica sagorijevanja na radnom mjestu nastavnika. 


\title{
PREVENTION OF PROFESSIONAL BURNOUT OF TEACHERS IN HIGHER EDUCATION
}

\begin{abstract}
- Abstract -
In this paper basic characteristics of stress and professional burnout are depicted, especially regarding the stress of teachers and professional burnout of teachers in higher education. We operationalised the most common terms in the respective field of research and discussed the factors which play a major role in onset and prevention of the work-related burnout. Regarding prevention the authors emphasised that it is more important to identify, and if it is possible to prevent and/or to eliminate the causes of professional burnout than to treat the burnout-syndrome after its outbreak. Prevention being the operative word here, and it is possible to realise it on both organisational and individual level, we offer guidelines and elucidate the activities within the prevention of professional burnout of teachers employed in institutions of higher education.
\end{abstract}

Keywords: professional burnout, stress, prevention, higher education.

\section{Literatura:}

- Amimo, C. A. (2012). Are you experiencing teacher burnout? A synthesis of research reveals conventional prevention and spiritual healing. Educationa Rersearch Journal. 2(11), 338-344.

- $\quad$ Dedić, G. (2005). Sindrom sagorijevanja na radu. Vojnosanitetski pregled. 62 (11): 851-855.

- Domović, V., Martinko, J., Jurčec, L. (2010). Čimbenici učiteljskog sagorijevanja na poslu. Napredak. 151 (3-4),

- 350-369.

- Hudek-Knežević, J., Kardum, I. (2006). Stres i tjelesno zdravlje. Naklada Slap: Jastrebarsko.

- Jennings, P. A., Greenberg, M. T. (2009). The prosocial classroom: Teacher Social and Emotional Competence in Relation to Student and Classroom Outcomes. Review of Educational Research. Vol. 79, No.1, 491-525.

- Koludrović, M., Jukić, T., Reić Ergovac, I. (2009). Sagorijevanje na poslu kod učitelja razredne i predmetne nastave te srednjoškolskih nastavnika. Život $i$ škola, br. 22, god. $55,235-249$. 
- Kovacs, G. (2010). Stressors leading to teacher burnout in adult education and ways of prevention helping the language teacher. Aarms, Vol. 9, No. 1, 117-123.

- $\quad$ Kravits, K., McAllister-Black, R., Grant, M., Kirk, C. (2010). Self-care strategies for nurses: A psycho-educational intervention for stress reduction and the prevention of burnout. Applied Nursing Research. 23, 130-138.

- $\quad$ Langle, A. (2003). Burnout - Existential Meaning and Possibilities of Prevention. European Psychotherapy. Vol. 4

- No. 1: 129-143.

- Maslach, C., Schaufeli, W. B., Leiter, M. P. (2001). Job Burnout. Annual Reviews Psychology, 52: 397-422.

- Martinko, J. (2010). Profesionalno sagorijevanje na poslu nastavnika u obrazovanju odraslih. Andragoški glasnik.

- Vol. 14, br. 2, 99-110.

- Pousette, A. (2001). Feedback and Stress in Human Service Organization. Goteborg. University of Gothenburg. Department of Psychology.

- Provini, C. (2013). Four essential ways to avoid educator burnout. Education Word.

- Dostupno na: http://www.educationworld.com/a_curr/top-ways-to-avoid-educatorburnout.shtml.

- $\quad$ Rakovec-Felser, Z. (2011). Professional Burnout - What to Do? Coll. Antropol. 35, 2: 577-585.

- Salami, S. O. (2011). Job Stress and Burnout among Lecturers: Personality and Social Support as Moderators. Asian Social Science. Vol. 7, No.5, 110-123.

- $\quad$ Slavin, R. E. (2009). Educational Psychology, Theory and Practice. Ninth Edition. Pearson International Edition.

- Slišković, A., Maslić Seršić D., Burić, I. (2012). Izvori stresa u radu nastavnika u visokom obrazovanju. Psihologijske teme 21, 1, 83-103.

- Weber, A., Jaekel-Reinhard, A. (2000). Burnout syndrome: a disease of modern societies? Occup. Med. Vol. 50, No. 7, 512-517.

- Wood, T., McCarthy, C. (2002). Understanding and Preventing Teacher Burnout. ERIC Clearinghouse on Teaching and Teacher Education Washington DC. Dostupno na: http://www.ericdigests.org/2004-1/burnout.htm. 